\title{
介護者支援を目的とした体位換用マットレスの開発 \\ Development of a mattress to assist care helper
}

○ シャハリアル アハメド 1 , 舟久保 昭夫 ${ }^{2}$, 福井 康裕 $^{2}$, 土肥 健純 ${ }^{3}$

1. 新潟産業大学 産業システム学部, 2. 東京電機大学 理工学部,

3. 東京大学大学院 情報理工学系研究科

OShahriar AHMED', Akio FUNAKUBO ${ }^{2}$, Yasuhiro FUKUI ${ }^{2}$, and Takeyoshi $\mathrm{DOHI}^{3}$

1. Faculty of Industrial Systems Ni igata Sangyo University,

2. Faculty of Science and Engineering. Tokyo Denki University.

3. Graduate School of Information science \& Technology. The University of Tokyo.

\section{1.はじめに}

寝たきりで長時間同じ体勢を維持し続けると, 体圧によ り特定の部分が圧迫される.裖瘡を引き起こす原因となる そのため病院や福祉施設等では, 一定の時間ごとに体位変 換をさせ、予防に努めている. しかし，介護者にとってこ の作業が肉体的にも精神的にも大きな負担になっている のが現状である。

本研究では上記の課題に対し, 要介護者に対し床ずれが 生じないよう体位姿勢を必要に応じて変化させ,介護者の負 担を軽減できるよう姿勢変換マットレスの開発を目指す.制御 機能を持ったこの介護マットレスは自然に人間が寝返りを打つ といら動作と同じで安静安眠の妨げにならないと考えられる。

\section{2. 機器の概要}

本システムに使用するマットレスは，防水性のライナー付き

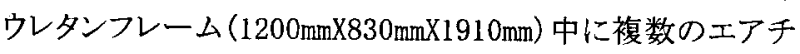
ヤンバー(両側:250X400 中央:200X400) からなるマットレスを 試作し, コンプレッサーから電磁弁を経由してエアチャンバー 内に圧縮空気を送り込む，抜き取る仕組みとなっている.コン トローラを使って空気の出し入れを制御する.エアチャンバー の内圧の計測には圧力ゲージを使用した。

\section{3. 研究結果}

まず，仰向け状態の体圧分布と体位を変換させた後の体 圧分布を比較し，一箇所に集中する圧力を移動可能かどう かを検討した．その結果Fig. 1 に示す．仰向け状態では、 ほぼ左右で同じくらいの体圧になっていることが確認で きる.さらに，中心にある骨突起部の圧力が高いことも色 濃度によって確認できる.これに対して体位換後の分布図 では、右半分全体の圧力が移動されていることが確認でき る.さらに，一番压力がかかっていた骨突起部の圧力も移 動されていることが確認された。

次に, 仰向け状態で右側のエアチャンバーに空気を送り 込み体位変換させ, チャンバーにかかっている内圧の変化 を測定, 比較した. 表 1 に示すように肩部, 剧部部分の内 圧は重心が移動している.しかし足の部分に関しては, エ アチャンバーの内圧変化が観測されなかった.この結果体 位変換させた時に足部分だけうまく重心が移動していな いことがわかった. 全身にかかる体重比率に問題があると

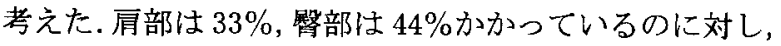
足部には 16\%しかかかっていないため同じように膨らま せるだけでは，退位変換ができなかったと考えた。

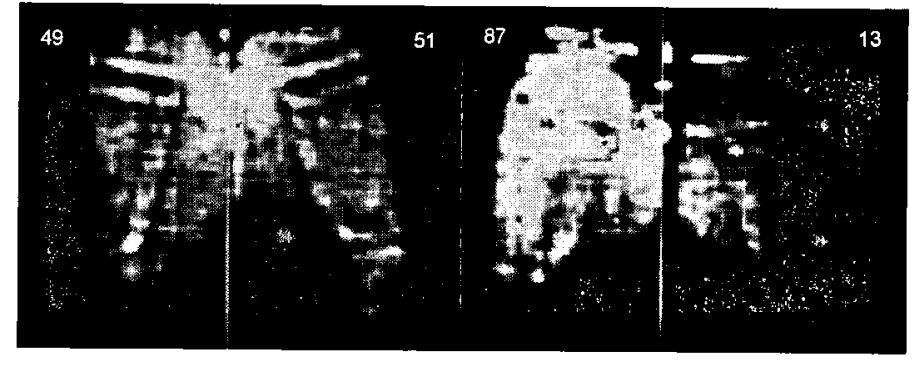

Fig. 1 左図に仰向け状態の锌部の圧力分布を示す, 右図に 体位変換させた後の圧力分布を示す。

表 1 体位変換前後の各チャンバーの内圧（単位 $100 \mathrm{kPa}$ )

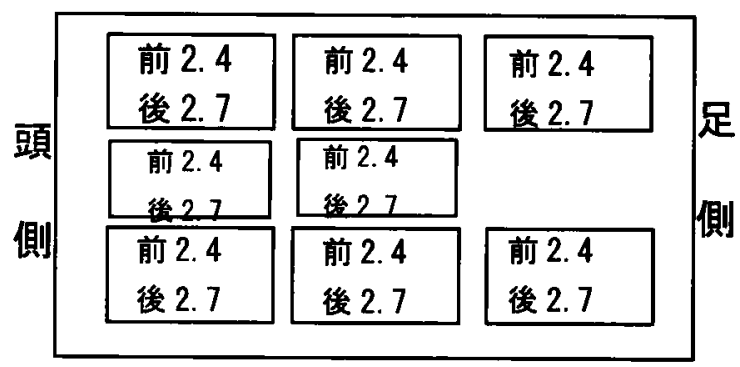

4. まとめ

体位変換をさせることにより全体の圧力の移動を行え， 最も值が高かった骨突起部の圧力も移動されていること がわかった。このことから，体位変換を繰り返し行うこと で裖㾑予防に繫がり介護者の肉体的負担を軽減できると 考える.

寝たきり高㱓者が増加傾向にあり，介護者の肉体的, 精 神的負担が多い中, 圧力の集中している部位を感知し自動 で体位変換マットレスが有効であると考えられる.

今後の課題として体位変換を自動で行えるための最適 な制御方法を導くつまり,エアチャンバー内に空気の出し 入れにかける時間を検討している.

\section{5. 参考文献}

1) 日野原重明, 松村秩, 大山好子 : リハビリテーション ナーシングマニュアル＼cjkstart臨床看護技術編

2）吉田敏子 : 看護学の基礎知識 